\title{
GREEN ONION PRODUCTION UNDER STRATEGIES OF REPLACEMENT AND FREQUENCIES OF CIRCULATION OF BRACKISH NUTRITIVE SOLUTIONS
}

\author{
PRODUÇÃO DE CEBOLINHA SOB ESTRATÉGIAS DE REPOSIÇÃO E \\ FREQUÊNCIAS DE CIRCULAÇÃO DE SOLUÇÕES NUTRITIVAS SALOBRAS
}

\section{Fernando José da SILVA JÚNIOR ${ }^{1}$, José Amilton SANTOS JÚNIOR ${ }^{2}$, Nildo da Silva DIAS ${ }^{3}$, Hans Raj GHEYI ${ }^{4}$, Rene Chipana RIVERA ${ }^{5}$, Gerônimo Ferreira da SILVA ${ }^{2}$, Cleyton dos Santos FERNANDES ${ }^{6}$}

1. Mestre em Engenharia Agrícola pela Universidade Federal Rural de Pernambuco, Recife, PE, Brasil; 2. Professor, Universidade Federal Rural de Pernambuco, Recife, PE, Brasil. eng.amiltonjr@ hotmail.com; 3. Professor, Universidade Federal Rural do Semi-Árido, Mossoró, RN, Brasil; 4. Professor visitante, Universidade Federal do Recôncavo da Bahia, Cruz das Almas, BA, Brasil; 5. Professor, Universidad Mayor de San Andrés, La Paz, Bolívia; 6. Mestrando em Manejo de Solo e Água, Universidade Federal Rural do SemiÁrido, Mossoró, RN, Brasil.

\begin{abstract}
The cultivation of vegetables in semi-arid regions, especially in the context of the use of brackish water, has been made possible by the use of the hydroponics technique. Thus, two experiments were carried out between December 2016 and January 2017 in a protected environment at the Federal Rural University of Pernambuco (UFRPE), Recife - PE, Brazil ( $8^{\circ} 1$ " 7 " South latitude and $34^{\circ} 56^{\prime}$ "53" West longitude, and average altitude of $6.5 \mathrm{~m}$ ), aiming at evaluating the production of green onion (cv. "Todo dia" Evergreen - Nebuka) in plants exposed to brackish nutrient solution $\left(1.5,3.0,4.5,6.0,7.5\right.$ and $\left.9.0 \mathrm{dS} \mathrm{m}^{-1}\right)$, applied at two frequencies of circulation (twice a day - at 8 and 16 hours, and three times per day - at 8, 12 and 16 hours) in low-cost hydroponics system. In Experiment I, the nutrient solution evapotranspirated by the plants was replaced with the respective brackish water used in its preparation, and in Experiment II with UFRPE supply water $\left(0.12 \mathrm{dS} \mathrm{m}^{-1}\right)$. In both cases, a completely randomized experimental design was used, in a $6 \times 2$ factorial scheme, with five replications. It was concluded that under replacement with brackish water, the increase in the frequency of circulation attenuated the losses imposed by the salinity to the biometric variables and of the production of fresh and dry phytomass of the plants; the water supply replenishment had a greater mitigating role in relation to the damage caused by the salinity with the increase of the electrical conductivity of the nutrient solution.
\end{abstract}

KEYWORDS: Allium fistulosum L. Cultivation without soil. Salinity.

\section{INTRODUCTION}

Green onion (Allium fistulosum L.) is one of the most popular condiment vegetables in human diet (CARDOSO; BERNI, 2012; ARAUJO et al., 2016). The most traditional cultivar is "Todo dia" Evergreen - Nebuka, widely used in the North and Northeast of Brazil; with leaves of light green color, it is characterized by the intense tillering forming clumps, so that its harvest occurs through cuts between 55 and 80 days after planting, when the leaves reach from 0.20 to $0.40 \mathrm{~m}$ height, and their sprouts can be harvested for two to three years (FILGUEIRA, 2008). However, when cultivated in a traditional manner, plant exposure to abiotic factors, such as salinity, may reduce the quantity and quality of the harvested product (ARAUJO et al., 2016).

In semi-arid environments, given their specific hydrogeological conditions, salinity promotes modifications in metabolic activities and affects cell elongation, reducing plant growth and in extreme cases can lead to death (SAIRAM; TYAGI, 2004), especially due to the osmotic levels, which coupled with the matrix potential, requires greater energy for the absorption of water and nutrients by the plant.

However, under hydroponic conditions, the water potential depends on the osmotic potential and, since there is no soil, the matrix potential is practically null (SOARES FILHO et al., 2016). Thus, it is necessary to adapt this technique to the needs and reality of small farmers, that is, a lowcost hydroponic system (SANTOS JÚNIOR et al., 2016) is an alternative for the production of vegetables in regions with water limitations, where the use of brackish water in agriculture is essential (SANTOS et al., 2010; SOARES et al., 2010; JESUS et al., 2015). 
Nevertheless, the adoption of strategies for the use of brackish water in hydroponic crops can further minimize the damage caused and potentiate the production of crops, especially vegetables (SOARES et al., 2010). Up to the present, significant results have been reported in vegetable cultivation using techniques such as nutrient solution preparation with brackish water and evapotranspiration replacement with regular supply water, due to the successive reduction of the concentration of salts at every replacement (ALVES et al., 2011; SOARES et al., 2010) and the use of higher frequencies of nutrient solution circulation due to the minimization of the variation in salt concentration and greater oxygenation of the solution (SOARES et al., 2016).

Therefore, the production of scallion (cv. "Todo dia" Evergreen - Nebuka) was evaluated in plants exposed to strategies of replacement and frequencies of circulation of brackish nutrient solutions.

\section{MATERIAL AND METHODS}

The experiments were carried out in a greenhouse at the Federal Rural University of Pernambuco, Recife - PE, Brazil ( $8^{\circ}$ 1"7" South latitude and $34^{\circ}$ 56" 53" West longitude, and average altitude of $6.5 \mathrm{~m}$ ) between December 2016 and May 2017. In this period, the average maximum and minimum temperatures were $37.4^{\circ} \mathrm{C}$ and 32.2 ${ }^{\circ} \mathrm{C}$, and the average maximum and minimum values of relative humidity were $61.4 \%$ and $44.5 \%$.

The experimental design was completely randomized, analyzed in a $6 \times 2$ factorial scheme, with five replications. The treatments consisted of six salinity levels of the nutrient solution $(1.5,3.0$,

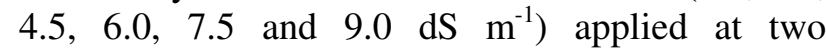
frequencies of circulation (twice a day - at 8 and 16 hours, and three times per day - at 8,12 and 16 hours). In the first experiment, the volume of nutrient solution evapotranspirated by plants was done with the respective brackish water used in its preparation and, in the second experiment, with water from the supply system $\left(0.12 \mathrm{dS} \mathrm{m}^{-1}\right)$.

The low-cost hydroponic system was composed of twelve PVC tubes with diameter of $100 \mathrm{~mm}$ and six meters long, arranged in level, with joints at the ends and, in one of them, a tap was installed to induce a level of four centimeters of solution along the tube. Cultivation was done in 180 $\mathrm{mL}$ disposable cups, filled with coconut fiber and perforated in the final third of the sides and bottom, which were placed in 60-mm-diameter holes, spaced by $14 \mathrm{~cm}$. Six wooden supports were used with a tube fixed at each end; these supports were reduced every $0.20 \mathrm{~m}$, the base support being $1.40 \mathrm{~m}$ and the top supporting $0.40 \mathrm{~m}$ (SANTOS JÚNIOR et al., 2016).

The evaluated culture was scallion (cv. "Todo dia" Evergreen - Nebuka), the sowing done directly in the disposable cups filled with coconut fiber; after sowing, these were inserted into the final tubes and received the solution of Furlani et al. (1999) up to 24 days. At 25 days after germination (DAG) the plants received saline treatments.

In relation to the preparation of the nutrient solution, $90 \mathrm{~L}$ of supply water (EC $0.12 \mathrm{dS} \mathrm{m}^{-1}$ ) were placed in twelve different containers, dissolving the amount of fertilizer recommended by Furlani et al. (1999). Subsequently, $\mathrm{NaCl}$ was added in adequate amounts, estimated on the basis of an empirical relationship proposed by Richards (1954), and the required levels of nutrient solution salinity were obtained.

Nutrient solution management was based on the recycling of water and nutrients (closed system), and evapotranspiration was replaced weekly according to each treatment as well as the frequency of circulation. However, at each circulation event, $40 \mathrm{~L}$ of nutrient solution was applied slowly, in order to homogenize and aerate the solution. In this process, as the tubes were level, excess solution flowed through the tap, set to keep the nutrient solution level inside the tube, and then returned to the reservoir. The parameters electrical conductivity (ECns) and $\mathrm{pH}$ of the nutrient solution ( $\mathrm{pHns}$ ) were monitored daily, making it unnecessary to make adjustments for the small variations.

The evaluated crop was green onion (cv. "Todo dia" Evergreen - Nebuka), which was sown directly in the disposable cups filled with coconut fiber; after sowing, these were inserted into the final tubes and received the solution of Furlani et al. (1999) until 24 days. At 25 days after germination (DAG), plants received saline treatments.

Production variables were evaluated at the end of the crop cycle (65 DAG), namely: total fresh phytomass, shoot fresh phytomass and root fresh phytomass per plant, that is, the respective fresh masses were collected and immediately weighed on a precision scale $(0.01 \mathrm{~g})$. Then they were dried in a forced ventilation oven at $65^{\circ} \mathrm{C}$ until reaching constant weight, to obtain total dry matter, shoot dry matter and root dry matter. With these variables, the percentages of total dry matter, shoot dry matter and root dry matter were calculated. Root length was measured from the stem insertion point to the root tip and plant height, from pseudostem base to the top of the last leaf. 
The results were submitted to analysis of variance by $F$ test. When a significant effect of the interaction between treatments was observed, the discussion was prioritized. In the other cases, quantitative factors were compared by regression analysis and qualitative factors by Tukey test at 0.05 probability level. All analyses were performed using statistical software (FERREIRA et al., 2011).

\section{RESULTS AND DISCUSSION}

When the evapotranspiration was replaced with brackish water, a tendency of accumulation of salts in the solution was observed, with a maximum increase of ECns, compared to the initial levels, observed under $3.0 \mathrm{dS} \mathrm{m}^{-1}$ (33\%) and $4.5 \mathrm{dS} \mathrm{m}^{-1}$ (31\%); at fourteen days after the start of saline treatments, in contrast, a decrease in pHns was registered, with the most significant reductions at ECns levels of $1.5 \mathrm{dS} \mathrm{m}^{-1}(14 \%)$ and $6.0 \mathrm{dS} \mathrm{m}^{-1}$ (11\%) from 39 days after planting (DAP).

When the replacement was performed with supply water, the trend was the reduction of ECns and, in treatments with $6.0 \mathrm{dS} \mathrm{m}^{-1}(18 \%)$ and $9.0 \mathrm{dS}$ $\mathrm{m}^{-1}(16 \%)$, a greater percentage decrease was observed after 39 (DAP). Regarding pHns, a downward trend was also observed, with a maximum reduction recorded at the ECns level of $1.5 \mathrm{dS} \mathrm{m}^{-1}$ (14\%) from 39 (DAP).

Thus, the oscillations of ECns and pHns when evapotranspiration was replaced with supply water were within the range recommended by Furlani et al. (1999), that is, a maximum ECns variation of $25 \%$ and $\mathrm{pH}$ between 5.5 and 6.5. In the case of the use of brackish water, the variation in ECns exceeded the maximum recommended variation due to the contributions of $\mathrm{NaCl}$ and was observed after fourteen days of adding $\mathrm{NaCl}$ to the nutrient solution. However, the pHns remained within the proposed range.

According to the results of the analysis of variance, total fresh phytomass (TFP), shoot fresh phytomass (SFP) and root fresh phytomass (RFP), as well as total dry matter (TDM), shoot dry matter (SDM) and root dry matter (RDM) were significantly influenced by the electrical conductivity $(\mathrm{p}<0.01)$ and the circulation frequency of the nutrient solution, as well as by the interaction between the treatments, under evapotranspiration replacement with brackish water or supply water.

Table 1. Summary of the F test for the fresh and dry total biomass of shoots and roots of green onion (cv. "Todo dia" Evergreen - Nebuka) as a function of the salinity levels and frequency of circulation of the nutrient solution considering strategies of replacement of the evapotranspired depth with brackish water (Experiment I) and with supply water (Experiment II).

\begin{tabular}{|c|c|c|c|c|c|c|c|c|c|c|c|c|c|}
\hline \multirow{3}{*}{$\begin{array}{l}\text { Source } \\
\text { variation }\end{array}$} & \multirow{3}{*}{ of $\mathrm{DF}$} & \multicolumn{12}{|c|}{ F Test } \\
\hline & & \multicolumn{2}{|c|}{ TFP } & \multicolumn{2}{|l|}{ SFP } & \multicolumn{2}{|l|}{ RFP } & \multicolumn{2}{|c|}{ TDM } & \multicolumn{2}{|l|}{ SDM } & \multicolumn{2}{|c|}{ RDM } \\
\hline & & $\overline{\mathrm{BW}}$ & SW & BW & SW & BW & SW & BW & SW & $\mathrm{BW}$ & SW & $\mathrm{BW}$ & SW \\
\hline Salinity (S) & 5 & 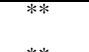 & 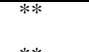 & & & & & & & & & & \\
\hline $\begin{array}{l}\text { Quadratic } \\
\text { regression }\end{array}$ & 1 & ** & ${ }^{* * *}$ & ns & ns & ${ }^{* * *}$ & ** & ns & *** & $\mathrm{ns}$ & ns & ns & *** \\
\hline Frequency $(\mathrm{F})$ & 1 & ** & ** & $* *$ & ** & $* *$ & $* *$ & ** & ** & $* *$ & ** & ** & $* *$ \\
\hline Interaction $\mathrm{S} \times \mathrm{F}$ & 5 & ** & ${ }^{* * *}$ & *** & ${ }^{* * *}$ & ${ }^{* * *}$ & $* *$ & ** & ** & $* *$ & ** & ** & *** \\
\hline Error & 48 & 48 & 48 & 48 & 48 & 48 & 48 & 48 & 48 & 48 & 48 & 48 & 48 \\
\hline $\mathrm{CV}$ & $\%$ & 9.51 & 3.59 & 1.70 & .77 & 3.29 & 10.73 & 0.36 & 6.14 & 2.77 & 6.96 & 9.29 & 13.25 \\
\hline
\end{tabular}

$\mathrm{DF}=$ degrees of freedom; $\mathrm{CV}=$ coefficient of variation; $* *=$ significant at 0.01 probability level; $*=$ significant at 0.05 probability level; ns = not significant. TFP, SFP and RFP = total fresh phytomass, shoot fresh phytomass and root fresh phytomass; TDM, SDM and $\mathrm{RDM}=$ total dry matter, shoot dry matter and root dry matter. BW = replacement with brackish water and $\mathrm{SW}=$ replacement with supply water.

The TFP of plants under replacement with brackish water (Figure 1A) was linearly reduced at rates of 0.1512 and $0.18181 \mathrm{~g}$ per $\mathrm{dS} \mathrm{m}^{-1}$ increased in ECns. On the other hand, when comparing the results of the plants under 1.7 and $9.0 \mathrm{dS} \mathrm{m}^{-1}$ losses were estimated to be $45.59 \%$ and $51.23 \%$, under two and three circulations per day, respectively, and frequency was not a mitigating factor $(p>0.05)$, except for $3.0 \mathrm{dS} \mathrm{m}^{-1}$.
The losses were lower $(45.17 \%$ and $39.57 \%$ ) when supply water was used (Figure 1B) in the replacement, with estimated decreases in the TFP of 1.6477 and $1.5236 \mathrm{~g}$, per unit increase of ECns, under two and three circulations per day, respectively. In this case, from $3.0 \mathrm{dS} \mathrm{m}^{-1}$ there were significant gains in the TFP when three circulations were used per day, emphasizing its mitigating role. Other vegetables under salt stress also show a reduction in TFP, as noted by Oliveira et al. (2013) 
who subjected arugula plants to ECns levels (1.2, 2.2, 3.2, 4.2 and $5.2 \mathrm{dS} \mathrm{m}^{-1}$ ) and observed a

(A)

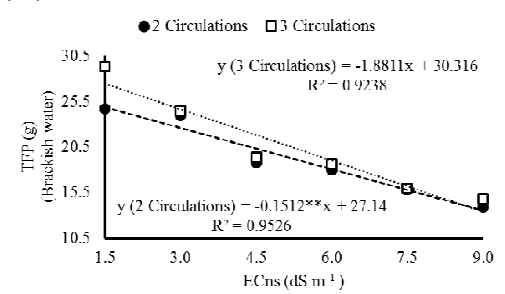

(C)

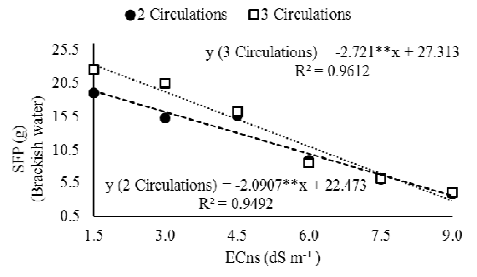

(E)

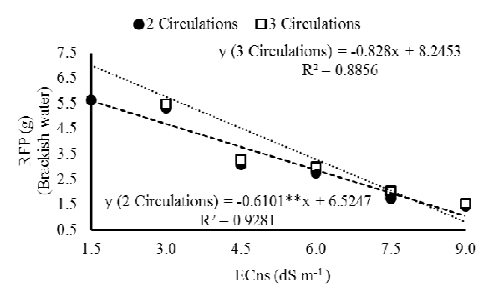

(G)

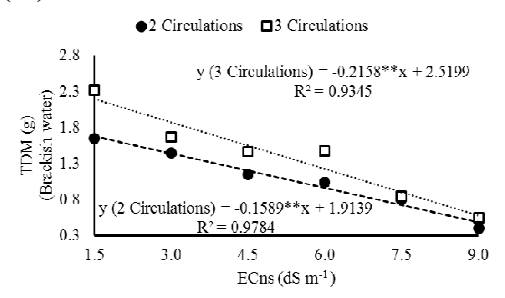

(I)

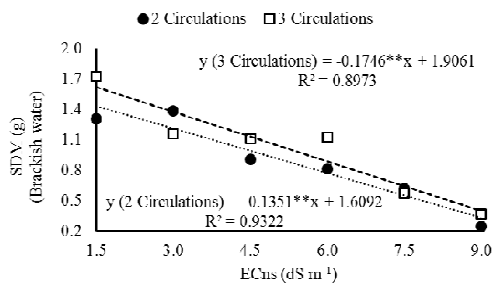

(K)

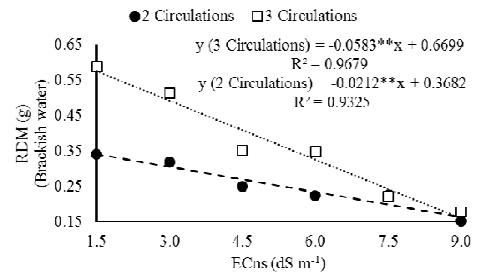

reduction in TFP in response to the increase in ECns.

(B)

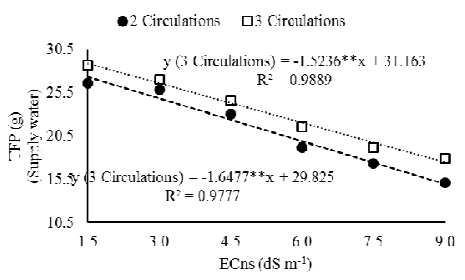

(D)

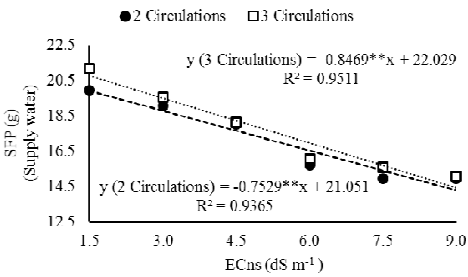

(F)

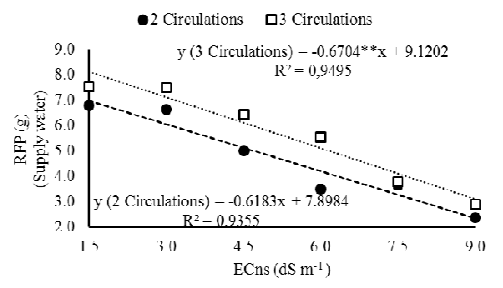

(H)

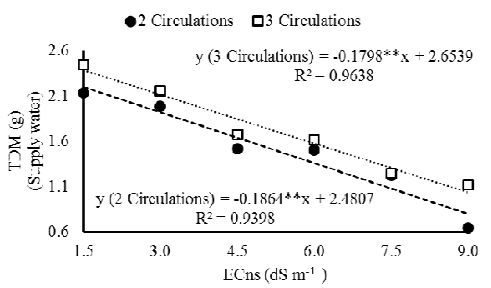

( J)

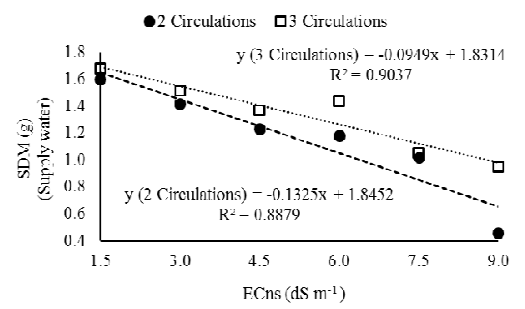

(L)

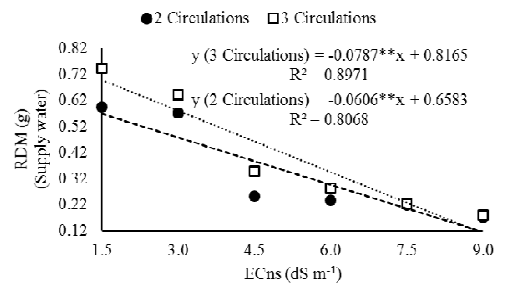

Figure 1. Results for green onion plants (cv. "Todo dia" Evergreen - Nebuka) under salinity and circulation frequencies of the nutrient solution replaced with brackish water and supply water. Follow-up test of the interaction between treatments for total fresh phytomass - TFP (A and B), shoot fresh phytomass - SFP (C and D), root fresh phytomass - RFP (E and F), total dry matter - TDM (G and $\mathrm{H}$ ), shoot dry matter - SDM (I and J) and root dry matter - RDM (K and L). Equal letters for each salinity level do not differ at 0.05 probability level. 
After analysis of the results with respect to SFP, it was observed that under replacement with brackish water (Figure 1C), the estimated results varied as a function of the frequency of nutrient solution circulation, with decreases of 2.721 and $2.0907 \mathrm{~g}$ per $\mathrm{dS} \mathrm{m} \mathrm{m}^{-1}$ increased in ECns, and when plants were compared under 1.5 and $9.0 \mathrm{dS} \mathrm{m}^{-1}$, the difference was up to $87.84 \%$ and $81.09 \%$ for two and three circulations per day, respectively. Similarly, under replacement with SW (Figure 1D), the decreases per unit increase in ECns were estimated at 0.8469 and $0.7529 \mathrm{~g}$, as well as at $25.4 \%$ and $30.60 \%$ compared to the SFP of plants under 1.5 and $9.0 \mathrm{dS} \mathrm{m}$, for two and three circulations per day, respectively. The reduction in SFP under salinity conditions has already been observed for several types of vegetables such as coriander (SILVA et al., 2014), lettuce (OLIVEIRA et al., 2011), and arugula (JESUS et al. 2015). In general, the authors attribute this reduction to the increase in energy demand for water and nutrient absorption under salinity conditions (TAIZ; ZEIGER, 2013).

With respect to the root, under replacement with brackish water, RFP decreased at rates of 0.6101 and $0.828 \mathrm{~g}$ per $\mathrm{dS} \mathrm{m} \mathrm{m}^{-1}$ increased in ECns, with estimated losses (in the interval between 1.5 and $9.0 \mathrm{dS} \mathrm{m}^{-1}$ ) of $81.57 \%$ and $88.67 \%$, under two and three circulations per day, respectively (Figure 1E). Under replacement with supply water, the losses per unit increase in ECns were estimated at 0.6138 and $0.6704 \mathrm{~g}$ and the total losses at $66.52 \%$ and $61.96 \%$ for two and three circulations of the solution per day, respectively (Figure 1F).

The estimated losses for shoot fresh phytomass were more expressive than those observed for the root, especially under replacement with brackish water. It is worth mentioning, however, the attenuating role of increasing circulation frequency for three circulations per day in favor of fresh phytomass, except under replacement with brackish water at levels above 7.5 $\mathrm{dS} \mathrm{m}^{-1}$. In all other cases, there was a reduction in the losses of the shoot in detriment of the root. The increase in the number of circulations per day probably reduced the concentration of the solution remaining inside the tube by frequent homogenization with the tank solution, in addition to increasing the volume supplied and oxygenation.

After the analysis of the interaction between treatments for TDM, there were decreases of 0.1589 and $0.2158 \mathrm{~g}$ per unit increase in ECns, as well as estimated losses of $71.12 \%$ and $73.69 \%$ within the proposed salinity range, under two and three circulations per day, respectively, in plants under replacement with brackish water (Figure 1G). Otherwise, when evapotranspiration was replaced with supply water, the estimated decreases per unit increment in ECns were 0.1864 and $0.1788 \mathrm{~g}$, with losses of $63.51 \%$ and $56.55 \%$ within the studied range of salinity, for two and three circulations per day, respectively (Figure $1 \mathrm{H}$ ). The increase in the frequency of circulation was important up to the level of $6.0 \mathrm{dS} \mathrm{m} \mathrm{m}^{-1}$ when the replacement was performed with brackish water, while no differences were found $(\mathrm{p}>0.05)$ from $3.0 \mathrm{dS} \mathrm{m}{ }^{-1}$ when supply water was used.

The SDM losses per unit increase in ECns $(0.1351 \mathrm{~g}$ and $0.1746 \mathrm{~g})$, as well as the difference in the shoot dry matter of the plants under 1.5 and 9.0 $\mathrm{dS} \mathrm{m}^{-1}(72.03 \%$ and $79.64 \%)$ were affected by the circulation frequencies of two and three times per day, respectively, under replacement with brackish water (Figure 1I). The response was similar to that of SW (Figure 1J), but with less intensity, so that the losses per unit increase in salinity $(0.1283 \mathrm{~g}$ and $0.1002 \mathrm{~g}$ ) and those estimated within the salinity range $(59.49 \%$ and $44.06 \%)$ varied for the frequencies of two and three times per day, respectively; in this case, from $6.0 \mathrm{dS} \mathrm{m}^{-1}$, influence $(p<0.05)$ was observed when the circulation frequency increased. The results presented corroborate the data found by Zanella et al. (2008), submitting lettuce plants (cv. Regina 2000 and Lucy Brown) in NFT hydroponic system to 15 minutes of circulation at intervals of 5,15 , and 30 minutes. These authors found that the highest accumulation of shoot dry matter occurred when a greater number of irrigation events were used per day.

In relation to the RDM, under replacement with brackish water (Figure $1 \mathrm{~K}$ ), the estimated losses per unit increment in ECns were 0.0212 and $0.0583 \mathrm{~g}$, with total decreases of $47.26 \%$ and $75.07 \%$, for circulation of two and three times per day, respectively. When SW was used (Figure 1L), at the estimated reductions were 0.0606 and 0.0787 $\mathrm{g}$ per $\mathrm{dS} \mathrm{m} \mathrm{m}^{-1}$, with losses of $80.10 \%$ and $84.50 \%$ within the salinity range, for two and three circulations of the solution per day, respectively. From $7.5 \mathrm{dS} \mathrm{m}{ }^{-1}$, for both replacement strategies, no significant increase in the circulation frequency was observed ( $p>0.05$ ) under RDM. However, for ECns lower than this value, the influence of this treatment was effective $(p<0.05)$. The results differ from those found by Silva et al. (2016), who subjected coriander plants to two types of brackish water (EC $=0.32 \mathrm{dS} \mathrm{m}^{-1}$ and $\mathrm{EC}=4.91 \mathrm{dS} \mathrm{m}^{-1}$ ) with four recirculation frequencies of the nutrient solution $(0.25 ; 2 ; 4$ and $8 \mathrm{~h})$, and observed that accumulation of root dry matter occurred independently of the 
recirculation frequencies of the nutrient solution, at the same level.

In a general analysis of dry matter, it is worth highlighting the importance of increasing the frequency of circulation under replacement with brackish water and emphasizing that, under replacement with $\mathrm{SW}$, the use of three circulations per day started to have a greater mitigating role with the increase of the ECns, due to the large number of nutrient solution circulation events, minimizing the effect of salinity on plants. Munns and Tester (2008) associate the reduction of dry phytomass to the osmotic effect of salinity, the toxic effect of $\mathrm{Na}^{+}$and
$\mathrm{Cl}^{-}$and the ionic imbalance caused by the excess of these ions.

Plants under increasing ECns exhibited significant variation $(\mathrm{p}<0.05)$ in \% TDM, \%SDM, $\%$ RDM, RL and PHG, for both nutrient solution replacement strategies. In relation to the frequency of circulation, under replacement with brackish water, there was significance $(\mathrm{p}<0.05)$ for \% TDM, $\%$ SDM, RL and PHG, and under replacement with supply water, for \%SDM and RL. The interaction between treatments influenced $(\mathrm{p}<0.05)$ the results of RL and PHG in both experiments (Table 2).

Table 2. F Test for the percentage of total dry matter (\%TDM), shoot dry matter (\%SDM) and root dry matter (\%RDM), for root length (RL) and for plant height (PHG) of green onion (cv. "Todo dia" Evergreen Nebuka) as a function of the salinity levels and frequency of application of the nutrient solution in the strategies of replacement with the respective brackish water and supply water (SW).

\begin{tabular}{|c|c|c|c|c|c|c|c|c|c|c|c|}
\hline \multirow{3}{*}{$\begin{array}{l}\text { Source } \\
\text { variation }\end{array}$} & \multirow{3}{*}{ DF } & \multicolumn{6}{|c|}{ F Test } & \multirow{2}{*}{\multicolumn{2}{|c|}{$\mathrm{RL}$}} & \multirow[b]{2}{*}{$\mathrm{PHG}$} & \multirow[b]{3}{*}{ SW } \\
\hline & & \multicolumn{2}{|c|}{$\% \mathrm{TDM}$} & \multicolumn{2}{|c|}{$\%$ SDM } & \multicolumn{2}{|c|}{$\%$ RDM } & & & & \\
\hline & & BW & SW & BW & SW & BW & SW & $\mathrm{BW}$ & SW & $\mathrm{BW}$ & \\
\hline Salinity (S) & 5 & & & & & & & & & & \\
\hline $\begin{array}{l}\text { Quadratic } \\
\text { regression }\end{array}$ & 1 & ns & ns & ns & $\mathrm{ns}$ & ns & $* *$ & $* *$ & $* *$ & ns & $* *$ \\
\hline Frequency $(\mathrm{F})$ & 1 & $* *$ & ns & ** & $* *$ & ns & $\mathrm{ns}$ & $* *$ & $* *$ & $* *$ & ns \\
\hline Interaction $\mathrm{SxF}$ & 5 & $\mathrm{~ns}$ & ns & ns & ns & $\mathrm{ns}$ & $\mathrm{ns}$ & $* *$ & $* *$ & $* *$ & $* *$ \\
\hline Error & 48 & 48 & 48 & 48 & 48 & 48 & 48 & 48 & 48 & 48 & 48 \\
\hline $\mathrm{CV}$ & $\%$ & 10.43 & 9.99 & 10.16 & 10.47 & 8.71 & 7.73 & 8.56 & 6.14 & 4.71 & 10.65 \\
\hline
\end{tabular}

$\mathrm{DF}=$ degree of freedom; $\mathrm{CV}=$ coefficient of variation; $* *=$ significant at 0.01 probability level; $\mathrm{ns}=$ not significant. $\mathrm{BW}=$ replacement with brackish water and $\mathrm{SW}=$ replacement with supply water.

After analysis of \%TDM, it was found that under replacement with brackish water and SW the reductions were estimated at 0.0802 and $0.3472 \%$ per $\mathrm{dS} \mathrm{m} \mathrm{m}^{-1}$ increased in ECns (Figure 2A). In relative terms, it was evident that the reduction in \%SDM had a smaller participation in the total losses, under both replacement strategies, brackish water $(0.2333 \%)$ and SW $(0.3042 \%)$ for every increase in $\mathrm{dS} \mathrm{m}^{-1}$ (Figure 2B), in comparison to the $\%$ RDM, whose estimates of the reduction per unit increase in ECns were 0.2429 and $0.4042 \%$ for brackish water and SW, respectively (Figure 2C). It is worth mentioning, however, that the frequency of circulation of the nutrient solution failed to attenuate the deleterious effect of salinity on the root, an organ directly exposed to stress.

In spite of the fact that $40 \%$ of the dry matter is composed of carbon (LAMBERS et al., 2008) and the deleterious impact of the ECns on the photosynthetically active area of the plant, a process responsible for its fixation, the replacement strategy with supply water and the increase in nutrient solution circulation frequency mitigated the effect of salts on dry matter in all parts of the plant. The higher root losses may be associated to the fact that, since this organ is directly exposed to salinity, it must perform osmotic adjustment (GUERZONI et al., 2014), thus reducing the rate of dry matter accumulation and also nutrient uptake, which are essential for plant development (DEINLEIN et al., 2014, RODRIGUES et al., 2014).

For RL, under replacement with brackish water, as a function of nutrient solution salinity within the circulation frequencies of this solution (Figure 2D), a linear reduction occurred at both frequencies, decreasing by 0.8981 and $0.8278 \mathrm{~cm}$ per $\mathrm{dS} \mathrm{m} \mathrm{m}^{-1}$ increased in ECns, with losses estimated at $43.36 \%$ and $38.90 \%$. On the other hand, when the evapotranspiration was replaced with SW (Figure $2 \mathrm{E})$, there were reductions of 0.9196 and $0.923 \mathrm{~cm}$, with estimated losses of $43.27 \%$ and $42.06 \%$ per unit increase in salinity with two and three solution circulations per day, respectively. This reduction in the roots is due to the direct contact and absorption of the saline solution, and consequently changes in the water relations of the cell, in which it prevents water absorption by the plant (WILLADINO et al., 2010). 
(A)

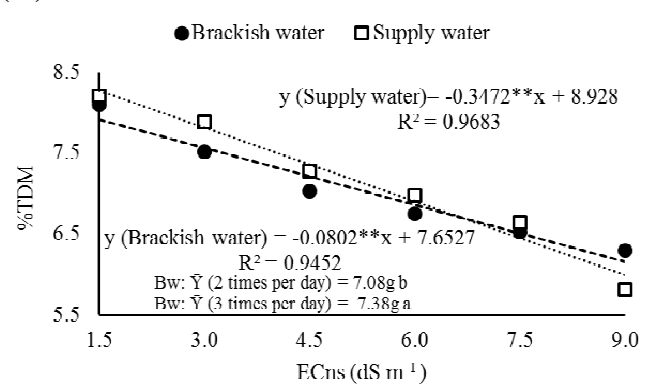

(C)

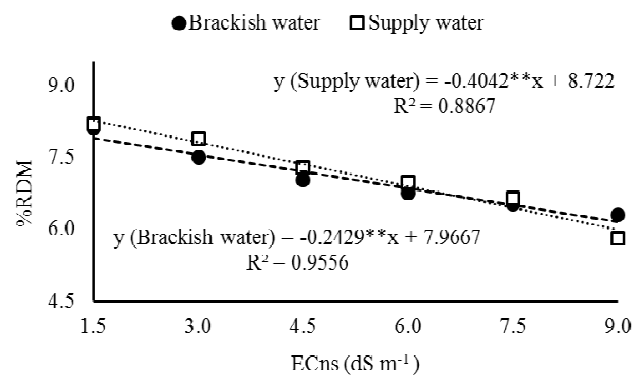

(E)

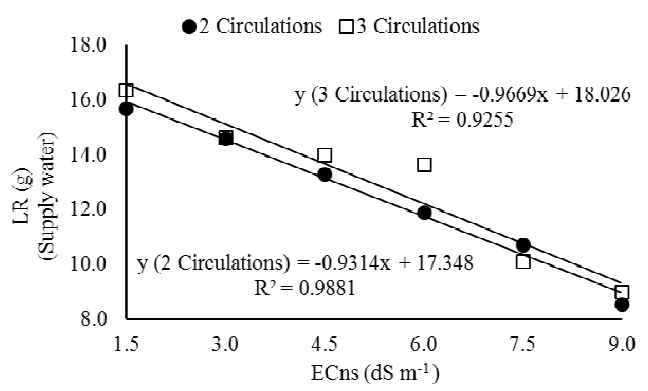

(G)

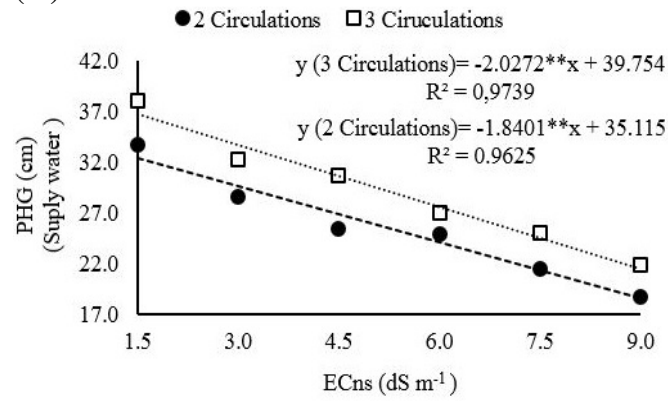

(B)

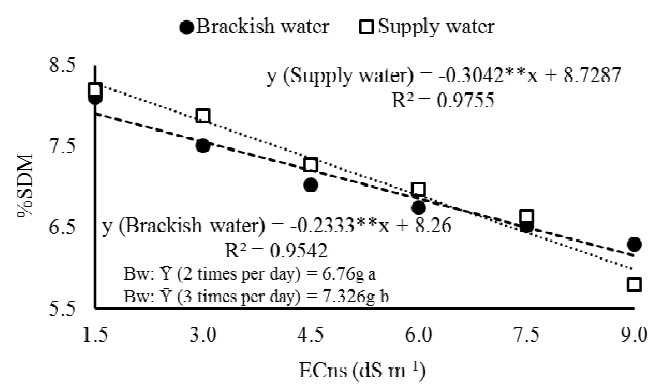

(D)

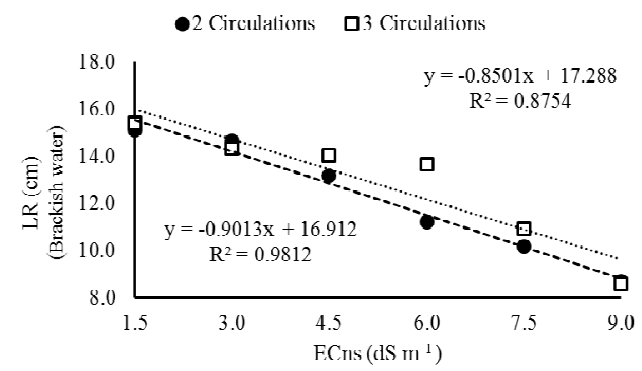

(F)

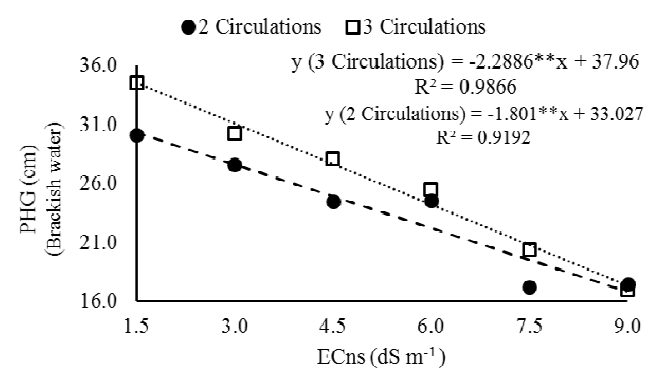

Figure 2. Results for green onion (cv. "Todo dia" Evergreen - Nebuka) due to strategies of brackish water use in hydroponic system. Percentage of total dry matter - \%TDM (A), shoot dry matter - \%SDM (B) and root dry matter - RDM (C) under replacement with brackish water and supply water. Follow-up test of the interaction between treatments for root length - RL (D and E) and plant height - PHG (F and $\mathrm{G})$. Equal letters for each salinity level do not differ at 0.05 probability level.

In the case of replacement with brackish water, it was observed that the height of the plants was linearly reduced, having estimated decreases of 1.801 and $2.2886 \mathrm{~cm}$ per $\mathrm{dS} \mathrm{m} \mathrm{m}^{-1}$ increased, with losses of $44.54 \%$ and $49.71 \%$ within the salinity range studied, under two and three circulations per day, respectively (Figure 2F). Likewise, when the evapotranspired depth was replaced with supply water (Figure 2G), reductions of 1.8401 and 2.0272 $\mathrm{cm}$ were observed per unit increase in ECns, with losses within the salinity range estimated at $42.65 \%$ and $41.41 \%$ under two and three circulations per day, respectively. Similar results were found by Silva et al. (2014) in studies with the green onion cv. "Todo dia". These authors observed that, at 30 days after transplanting, plants subjected to saline level of $0.7 \mathrm{dS} \mathrm{m}^{-1}$ began to decrease by $7.0 \%$ per 
unit increase in salinity, and the difference between the highest and the lowest saline level was $19 \%$.

\section{CONCLUSIONS}

The use of three circulations of the solution per day attenuated the losses of the biometric variables and the production of fresh and dry phytomass of the plants under replacement with brackish water, and when supply water was adopted, it began to have a greater mitigating role with the increase in nutrient solution salinity.

The increase in nutrient solution salinity reduced the percentage of total dry matter, shoot dry matter and root dry matter; however, increasing the frequency of circulation of the nutrient solution did not mitigate the deleterious effect of salinity on the percentage of dry matter of the root, an organ directly exposed to saline stress.

\section{ACKNOWLEDGMENT}

The authors would like to thank the National Council for Scientific and Technological Development $(\mathrm{CNPq})$ for the financing of the project.

RESUMO: O cultivo de hortaliças em regiões semiáridas, especialmente no contexto de uso de águas salobras, tem sido viabilizado pelo uso da técnica da hidroponia. Diante disto, entre janeiro de 2016 e abril de 2017, foram conduzidos dois experimentos em ambiente protegido na Universidade Federal Rural de Pernambuco (UFRPE), Recife, PE ( $8^{\circ}$ 1"7" Sul e 34 56" 53" Oeste, altitude média de 6,5 m), objetivando-se avaliar a produção da cebolinha (cv. Todo ano Evergreen - Nebuka) em plantas expostas a soluções nutritivas

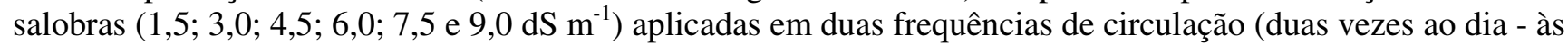
8 e às 16 horas; e três vezes ao dia - às 8,12 e 16 horas). Em ambos os casos, utilizou-se um delineamento experimental inteiramente casualizado, em esquema fatorial $6 \times 2$, com cinco repetições. No Experimento I, a lâmina de solução nutritiva evapotranspirada pelas plantas foi reposta com a respectiva água salobra utilizada no seu preparo e, no Experimento II, com água de abastecimento da UFRPE $\left(0,12 \mathrm{dS} \mathrm{m}^{-1}\right)$. Concluiu-se que sob reposição com água salobra, o aumento da frequência de circulação atenuou as perdas impostas pela salinidade às variáveis biométricas e de produção de fitomassa fresca e seca das plantas; a reposição com água de abastecimento passou a ter maior papel mitigador em relação ao dano causado pela salinidade com o aumento da condutividade elétrica da solução nutritiva.

PALAVRAS-CHAVES: Allium fistulosum L. Cultivo sem solo. Salinidade.

\section{REFERENCES}

ALVES, M. S.; SOARES, T. M.; SILVA, L. T.; FERNANDES, J. P.; OLIVEIRA, M. L. A; PAZ, V. P. S. Estratégias de uso de água salobra na produção de alface em hidroponia NFT. Revista Brasileira de Engenharia Agrícola e Ambiental, Campina Grande, v. 15, n. 5, p. 491-498, 2011. http://dx.doi.org/10.1590/S1415-43662011000500009

ARAUJO, J. L.; FAQUIN, V.; BALIZA, D. P.; ÁVILA, F. W.; GUERRERO, A. C. Crescimento e nutrição mineral de cebolinha verde cultivada hidroponicamente sob diferentes concentrações de N, P e K. Revista Ceres, Viçosa, v. 63, n. 2, p. 232-240, 2016. http://dx.doi.org/10.1590/0034-737X201663020015

DEINLEIN, U.; STEPHAN, A. B.; HORIE, T.; LUO, W.; XU, G.; SCHROEDER, J. I. Plant salt-tolerance mechanisms. Trends in Plant Science, Oxford, v. 19, n. 6, p. 371-9, 2014. https://doi.org/10.1016/j.tplants.2014.02.001

FERREIRA, D. F. Sisvar: a computer statistical analysis system. Ciência e Agrotecnologia, Lavras, v. 35, n. 6 , p. 1039-1042, 2011. http://dx.doi.org/10.1590/S1413-70542011000600001

FILGUEIRA, F. A. R. Novo manual de olericultura: agrotecnologia moderna na produção e comercialização de hortaliças. 3. ed. Viçosa: UFV, 2008. 421 p. 
FURLANI, P. R. Hydroponic vegetable production in Brazil. Acta Horticulturae, Wageningen, v. 2, n. 481, p. 777-778, 1999. http://dx.doi.org/10.17660/ActaHortic.1999.481.98

GUERZONI, J. T. S.; BELINTANI, N. G.; MOREIRA, R. M. P.; HOSHINO, A. A.; DOMINGUES, D. S.; BESPALHOK FILHO, J. C.; VIEIRA, L. G. E. Stress-induced D1-pyrroline-5-carboxylate synthetase (P5CS) gene confers tolerance to salt stress in transgenic sugarcane. Acta Physiologiae Plantarum, Krakow, v. 36, n. 9, p. 309-2319, 2014. https://doi.org/10.1007/s11738-014-1579-8

JESUS, C. G.; SILVA JÚNIOR, F. J.; CAMARA, T. R.; SILVA, Ê. F. F.; WILLADINO, L. Production of rocket under salt stress in hydroponic systems. Horticultura Brasileira, Brasília, v. 33, n. 4, p. 493-497, 2015. http://dx.doi.org/10.1590/S0102-053620150000400014

LAMBERS, H.; CHAPIN, F.; PONS, T. Plant physiological ecology. New York: Springer, 2008. 540 p. https://doi.org/10.1007/978-0-387-78341-3

OLIVEIRA, F. A.; SOUZA NETA, M. L.; SILVA, R. T.; SOUZA, A. A. T.; OLIVEIRA, M. K. T.; MEDEIROS, J. F. Desempenho de cultivares de rúcula sob soluções nutritivas com diferentes salinidades. Revista Agro@mbiente On-line, Boa vista, v. 7, n. 2, p. 170-178, 2013. http://dx.doi.org/10.18227/19828470ragro.v7i2.940

MUNNS, R.; TESTER, M. Mechanisms of Salinity Tolerance. Review Anual of Plant Biology, Palo Alto, v. 59, n. 1, p. 651-681, 2008. https://doi.org/10.1146/annurev.arplant.59.032607.092911

OLIVEIRA, F. D. A.; MARIA, J. D. O.; MEDEIROS, J. F.; MARACAJÁ, P. B.; OLIVEIRA, M. K. Desempenho de cultivares de alface submetidas a diferentes níveis de salinidade da água de irrigação. Revista Brasileira de Engenharia Agrícola e Ambiental, Campina Grande, v. 15, n. 8, p. 771-778, 2011. http://dx.doi.org/10.1590/S1415-43662011000800002

RICHARDS, L. A. Diagnosis and improvement of saline and alkali soils. Washington, DC.: U.S. Department of Agriculture, 1954. 160 p. (Agricultural Handbook, 60)

RODRIGUES, C. R. F.; SILVA, E. N.; MOURA, R. M., ANJOS, D. C.; HERNANDEZ, F. F. F.; VIÉGAS, R. A. Physiological adjustment to salt stress in $R$. communis seedlings is associated with a probable mechanism of osmotic adjustment and a reduction in water lost by transpiration. Industrial Crops and Products, Amsterdam, v. 54, n. 3, p. 233-239, 2014. https://doi.org/10.1016/j.indcrop.2013.12.041

SAIRAM, R. K.; TYAGI, A. Physiology and molecular biology of salinity stress tolerance in plants. Current Science, Bangalore, v.86, n.3, p.407-421, 2004. http://www.jstor.org/stable/24108735

SANTOS JÚNIOR, J. A.; GHEYI, H. R.; CAVALCANTE, A. R.; DIAS, N. S.; MEDEIROS, S. S. Produção e pós-colheita de flores de girassóis sob estresse salino em hidroponia de baixo custo. Engenharia Agrícola, Jaboticabal, v. 36, n. 3, p. 420-432, 2016. http://dx.doi.org/10.1590/1809-4430-Eng.Agric.v36n3p420-432/2016

SANTOS JÚNIOR, J. A.; GHEYI, H. R.; GUEDES FILHO, D. H.; DIAS, N. S.; SOARES, F. A. L. Efficiency of water use for sunflower grown in hydroponic system under salt stress. Engenharia Agrícola, Jaboticabal, v. 33, n. 4, p. 718-729, 2013. http://dx.doi.org/10.1590/S0100-69162013000400011

SANTOS JÚNIOR, J. A.; GHEYI, H. R.; GUEDES FILHO, D. H.; DIAS, N. S.; SOARES, F. A. L. Cultivo de girassol em sistema hidropônico sob diferentes níveis de salinidade. Revista Ciência Agronômica, v. 42, n. 4 , p. 842-849, 2011. http://dx.doi.org/10.1590/S1806-66902011000400004

SILVA, F. V.; DUARTE, S. N.; LIMA, C. J. G. S.; DIAS, N. S.; SANTOS, R. S. S.; MEDEIROS, P. R. F. Cultivo hidropônico de rúcula utilizando solução nutritiva salina. Revista Brasileira de Ciências Agrárias, Recife, v. 8, n. 3, p. 476-482, 2013. http://dx.doi.org/10.5039/agraria.v8i3a1689 
Silva, P.F; CAVAlCANTE, V. S.; SAntos, J. C. C.; COSTA, E. S.; BARBORA, J. T. V. Análise quantitativa da cebolinha irrigada com água salina. Comunicata Scientiae, Bom Jesus, v. 5, n. 3, p. 241-251, 2014.

SILVA, M. G. D., SOARES, T. M., GHEYI, H. R., OLIVEIRA, I. D. S., SILVA FILHO, J. A. D.; CARMO, F. F. D. Frequency of recirculation of nutrient solution in hydroponic cultivation of coriander with brackish water. Revista Brasileira de Engenharia Agrícola e Ambiental, Campina Grande, v. 20, n. 5, p. 447-454, 2016. http://dx.doi.org/10.1590/1807-1929/agriambi.v20n5p447-454

SOARES, T. M.; DUARTE, S. N.; SILVA, E. F. F.; JORGE, A. C. Combinação de águas doce e salobra para produção de alface hidropônica. Revista Brasileira de Engenharia Agrícola e Ambiental, Campina Grande, v.14, n.7, p.705-714, 2010. http://dx.doi.org/10.1590/S1415-43662010000700004

SOARES, T. M.; DUARTE, S. N.; SILVA, E. F. F.; PAZ, V. P. S.; BARCELOSOLIVEIRA, J. L. Uso de águas salobras em sistemas hidropônicos de cultivo. In: GHEYI, H. R.; DIAS, N. S.; LACERDA, C. F. (Eds.). Manejo da salinidade na agricultura: Estudo básico e aplicados. Fortaleza: INCTSal, 2016. p. 373- 390.

SOARES FILHO, W. S.; GHEYI, H. R.; B. BRITO, M. E. B.; NOBRE, R. G.; FERNANDES, P. D.; MIRANDA, R. S. Melhoramento genético e seleção de cultivares tolerantes à salinidade. In: GHEYI, H. R.; DIAS, N. S.; LACERDA, C. F. (Ed.) Manejo da salinidade na agricultura: Estudos básicos e aplicados. Fortaleza: INCTSal, 2016. p. 259-277.

TAIZ, L.; ZEIGER, E. Fisiologia vegetal. 5. ed. Porto Alegre: Artmed, 2013. 918 p.

WILLADINO, L.; CAMARA, T. R. Tolerância das plantas à salinidade: aspectos fisiológicos e bioquímicos. Enciclopédia Biosfera, Goiânia, v. 6, n. 11, p. 1-23, 2010.

ZANELLA, F.; LIMA, A. L. S.; SILVA JÚNIOR, F. F.; MACIEL, S. P. A. Crescimento de alface hidropônica sob diferentes intervalos de irrigação. Ciência e Agrotecnologia, Lavras, v. 32, n. 2, p. 366-370, 2008. http://dx.doi.org/10.1590/S1413-70542008000200003 